\title{
EFEKTIVITAS BUBUK KOPI ROBUSTA FUNGSIONAL DIFORTIFIKASI BUBUK DAUN KERSEN TERHADAP PENURUNAN KADAR GULA DARAH MENCIT DIABETES
}

\author{
[The Effectiveness of Functional Robusta Coffee Powder Fortified by Muntingia calabura L. Leaves \\ Powder to Lower Blood Glucose Level in Diabetic Mice] \\ Imam Adriansyah*, Dody Handito dan Rucitra Widyasari \\ Program Studi Ilmu dan Teknologi Pangan, Fakultas Teknologi Pangan dan Agroindustri, \\ Universitas Mataram \\ *Email: Adriansyah.imam555@gmail.com
}

Diterima 28 Desember 2020 / Disetujui 06 Juli 2020

\begin{abstract}
The aim of this present study was to determine the effectiveness of fucntional Robusta coffee powder fortified by Muntingia calabura L. leaves to lower blood glucose level in diabetic mice according to the antioxidant activity and total phenolic content, and the effectivness of the chosen ratio of the antidiabetic functional coffee beverage to the body weight and blood glucose level in diabetic mice. This research was conducted in two stages. First, determining the best ratio of the antidiabetic functional coffee beverage using randomized complete design. Second, testing the best ratio to the speciment using the randomized post testonly control group design to perform the chosen ratio of the antidiabetic functional coffee beverage to diabetic mice in seven days treatment. The results showed that the best ratio of the antidiabetic functional coffee beverage was $25 \%$ robusta coffee powder and $75 \%$ Muntingia calabura L. leaves powder with $88.26 \%$ antioxidant activity and $1.05 \mathrm{mg} \mathrm{GAE} / \mathrm{g}$ sample, and the chosen ratio of the antidiabetic functional coffee beverage proved the activity to reduce the blood glucose level in diabetic mice with the decrease level was $266 \mathrm{mg} / \mathrm{dl}$ or $45 \%$ effective to reduced the blood glucose level in diabetic mice. This blood glucose reduced activity was not significant to the positive control group given glibenclamid, but it was found significant to the negative control group that given aquades per oral. While the body weight of the diabetic mice given aquades only decreased twice higher than positive control group and antidiabetic functional coffee beverage group.
\end{abstract}

Keywords: blood glucose level, diabetic, Muntingia calabura L. leaves, robusta coffee

\section{ABSTRAK}

Tujuan dari penelitian ini adalah untuk menentukan rasio terbaik antara bubuk kopi robusta dan bubuk daun kersen sebagai minuman fungsional yang difortifikasi bubuk daun kersen terhadap penurunan kadar gula darah mencit diabetes, yang ditinjau dari aktivitas antioksidan dan kadar fenolik total, serta pengaruh rasio terpilih terhadap berat badan dan penurunan kadar gula darah mencit diabetes. Penelitian ini dilakukan dalam dua tahap, yang pertama yaitu penentuan rasio terbaik antara bubuk kopi robusta dan bubuk daun kersen menggunakan metode rancangan acak lengkap (RAL) dengan faktor tunggal berupa rasio bubuk kopi robusta dan bubuk daun kersen. Kedua, yaitu pengujian rasio terbaik pada hewan percobaan menggunakan metode rancangan acak dengan tes akhir dan kelompok kontrol dengan parameter kadar gula darah dan berat badan mencit selama tujuh hari perlakuan. Hasil dari penelitian ini adalah rasio terbaik dari kopi fungsional antidiabetes diperoleh dari rasio $25 \%$ bubuk kopi robusta dan $75 \%$ bubuk daun kersen dengan aktivitas antioksidan sebesar $88,26 \%$ dan kadar fenolik total sebesar 1,05 mg GAE/g bahan. Berdasarkan uji in vivo, produk kopi fungsional antidiabetes mampu menurunkan kadar gula darah mencit diabetes sebesar $266 \mathrm{mg} / \mathrm{dl}$ atau sekitar 45\%, tidak berbeda nyata dengan perlakuan kontrol positif yang diberikan obat glibenklamid dengan penurunan sebesar $268 \mathrm{mg} / \mathrm{dl}$ atau sekitar 47\%, namun berbeda nyata dengan kelompok perlakuan kontrol negaif menggunakan aquades yang mengalami peningkatan kadar gula darah sebsar $4,2 \%$. Sedangkan untuk parameter berat badan, bahwa penurunan berat badan mencit kelompok perlakuan kontrol negatif menggunakan aquades mengalami penurunan dua kali lebih besar dibandingkan kelompok kontrol positif dan kelompok produk kopi fungsional.

Kata kunci: daun kersen, diabetes, kadar gula darah, kopi robusta

\section{PENDAHULUAN}

Berdasarkan data yang diperoleh dari 130 negara di dunia, terdapat 382 juta jiwa menderita diabetes selama tahun 2013 dan diperkirakan jumlah ini akan terus meningkat hingga 592 juta jiwa pada tahun 2035. Sebagian besar penderita diabetes tersebut berasal dari negara berpenghasilan rendah dan menengah (Guariguata $d k k$., 2014). Di Indonesia, data Riset Kesehatan Dasar 
(Riskesdas) 2013 menunjukkan prevalensi diabetes sekitar 6,9 persen, meningkat dari data Riskesdas 2007 yang mencatat 5,7 persen. Kementerian Kesehatan memperkirakan hanya 30 persen pasien diabetes yang terdiagnosis (Badan Penelitian dan Pengembangan Kesehatan, 2013). Penanganan penyakit diabetes umumnya menggunakan obat-obatan sintetis seperti glibenklamid, metformin, maupun kombinasi keduanya (Harfina $d k k$, 2012). Namun, penggunaan obat sintetis memiliki efek samping terhadap tubuh yang lebih besar dibandingkan dengan obat tradisional (Sari, 2006).

Salah satu upaya preventif dan treatment untuk mengurangi resiko dan komplikasi diabetes dengan efek samping yang jauh lebih rendah adalah melalui konsumsi pangan fungsional. Hal ini senada dengan yang dinyatakan oleh Sani dkk., (2014) bahwa konsumsi pangan fungsional akan dirasa lebih tepat di mana selain kita bisa mendapatkan zat gizi, kita juga bisa mendapatkan senyawa bioaktif yang bersifat alami dari bahan pangan fungsional tersebut. Beberapa bahan alami yang dapat dikembangkan sebagai pangan fungsional penurun kadar gula darah dan ditemukan dalam jumlah yang banyak adalah daun kersen (Muntingia calabura) dan kopi robusta (Coffea canephora).

Kopi memiliki kandungan antioksidan yang cukup baik. Selain sebagai sumber utama kafein, kopi juga mengandung beberapa senyawa terutama fenol, vitamin B3, magnesium, potasium dan serat (Castelnuovo $d k k_{.}, 2012$ ). Hasil penelitian Paynter (2006) menyatakan bahwa apabila seseorang meminum kopi sebanyak 4 gelas perhari, maka akan memiliki resiko terkena diabetes sebesar $23 \%$ lebih rendah dibandingkan dengan seseorang yang tidak meminum kopi. Hal ini disebabkan oleh adanya kandungan asam klorogenat yang terdapat dalam biji kopi yang diduga memiliki potensi untuk menghambat enzim aglukosidase. Menurut Clarke dan Macrae (1987) kandungan asam klorogenat pada biji kopi robusta lebih tinggi dibandingkan biji kopi arabika, yaitu 7,0-10,0 berbanding 5,58,0. Selain itu, menurut Chandra $d k k$. (2012), masyarakat Indonesia lebih menyukai untuk mengonsumsi kopi jenis robusta dibanding arabika karena harganya yang relatif lebih murah dan rasanya yang khas. Oleh karena itu, dalam penelitian ini digunakan kopi jenis robusta.

Daun kersen juga memiliki kandungan antioksidan yang cukup baik dengan nilai IC 50 sebesar $22 \mu \mathrm{g} / \mathrm{ml}$ (Siddiqua $d k k ., 2010)$ dan telah digunakan sebagai obat antidiabetes oleh masyarakat Lombok secara turun-temurun dari generasi ke generasi. Menurut Kuntorini $d k k$, (2013) Daun kersen mengandung senyawa flavonoid, saponin, polifenol dan tannin sehingga dapat digunakan sebagai antioksidan. Aktivitas antioksidan pada daun kersen tua lebih kuat dengan nilai IC $_{50}$ sebesar 18,214 ppm dibandingkan dengan aktivitas antioksidan pada daun kersen muda dengan nilai IC 50 sebesar 21,786 ppm. Sedangkan, Kadar fenolat total dari ekstrak air daun kersen menurut penelitian Marjoni dkk. (2015) adalah sebesar 2,86 mg/50 g.

Pemanfaatan daun kersen sebagai minuman obat antidiabetes oleh masyarakat dilakukan dengan cara merebus daun kersen kemudian air hasil rebusan diminum. Berdasarkan penelitian Stevani dkk. (2017), rebusan daun kersen dengan konsestrasi $15 \%$ efektif menurunkan kadar glukosa darah mencit dibandingkan rebusan daun kersen dengan konsentrasi $5 \%$ dan $10 \%$ dan rata-rata penurunan sebesar $98 \mathrm{mg} / \mathrm{dl}$. Ratarata penurunan ini mendekati rata-rata penurunan kadar glukosa darah mencit yang diberikan suspensi obat glibenklamid. Menurut Utama (2011), frkasi etil asetat daun kersen memiliki aktivitas sebagai antidiabetes. Fraksi etil asetat daun kersen dosis $240 \mathrm{mg} / \mathrm{kgBB}$ memberikan efek antidiabetes terbesar dibandingkan kelompok perlakuan yang lain. Senyawa yang terkandung di dalam fraksi etil asetat daun kersen adalah flavonoid, terpenoid dan polifenol. 
Namun, rasa pahit dan sedikit sepat serta aroma yang kurang menyenangkan dari rebusan daun kersen membuat beberapa orang tidak tertarik untuk mengkonsumsinya. Rasa pahit dan sedikit sepat ini mirip dengan rasa khas dari kopi robusta serta aroma yang kurang menyenangkan ini diharapkan dapat tertutupi oleh aroma khas dari kopi robusta. Oleh karena itu, penelitian mengenai Efektivitas Bubuk Kopi Robusta Fungsional Yang Difortifikasi Bubuk Daun Kersen Terhadap Penurunan Kadar Gula Darah Mencit Diabetes dilakukan.

Adapun tujuan dari penelitian ini adalah untuk mengkaji rasio bubuk kopi robusta dan bubuk daun kersen sebagai minuman kopi fungsional antidiabetes yang ditinjau dari aktivitas antioksidan dan kadar fenolik total produk, serta efektivitas produk dalam mengurangi kadar gula darah dan meminimalisir penurunan berat badan mencit yang dikondisikan diabetes.

\section{BAHAN DAN METODE}

\section{Bahan}

Bahan-bahan yang digunakan antara lain: Biji kopi Robusta yang diperoleh dari petani kopi di Kabupaten Sumbawa Barat, daun kersen yang diperoleh dari pohon kersen di lingkungan Universitas Mataram, pakan standar tikus BR-2 (mengandung air, abu, protein dan serat kasar), Bahan kimia yang digunakan untuk pengujian yaitu aquades, asam galat, methanol, $\mathrm{NaCl}$, Alloxan monohidrat, pakan standar, larutan DPPH 0,1 M, Na2CO3 7\%, Folin ciocalteu, Glibenklamid $5 \mathrm{mg}$ dan mencit galur BALB-C jantan.

\section{Alat}

Alat-alat yang digunakan antara lain: Spektrofotometer UV-Vis merek Thermo tipe Evolution 201, Neraca analitik, Timbangan digital tipe SF-400C, vortex $2.500 \mathrm{rpm}$ merek Heidolph, Sentrifus $15.000 \mathrm{rpm}$ merek Hettich tipe Universal 320, Cabinet dryer, roaster, grinder latina $600 \mathrm{~N}$, tabung reaksi merek Zyrex Iwaki, pipet ukur, pipet mikro, rak tabung reaksi, rubber bulb merek merk
Vitlab, erlenmeyer merek Schott Duran, gelas piala, labu ukur $100 \mathrm{ml}$ merek Herma, kandang mencit, ayakan mesh 40, blender merek Panasonic, gunting medis, jarum suntik (syringe) merek One Med, jarum sonde (force feeding needle), alat glukometer dan strip glukometer merek Autocheck.

\section{Metode}

Metode yang digunakan dalam penelitian ini adalah metode eksperimental yang dilaksanakan di Laboratorium dengan tahapan penelitian meliputi: pembuatan bubuk daun kersen (Puspitasari dan Lean, 2017 dengan modifikasi), pembuatan bubuk kopi robusta (Purwaningsih, dkk (2002) dengan modifikasi), pemformulasian kopi fungsional dengan 6 rasio berbeda, pengujian aktivitas antioksidan dan kadar fenolik total, pelarutan kopi fungsional dan pengaplikasian pada hewan percobaan (Mayaswari, 2017). Hewan percobaan yang digunakan adalah mencit galur BALB/C jantan yang berusia 2-3 bulan dengan berat 20-30 g dan dikondisikan diabetes melalui induksi aloksan dengan dosis $125 \mathrm{mg} / \mathrm{Kg} \mathrm{BB}$ mencit secara intraperitoneal. Parameter yang diamati meliputi aktivitas antioksidan dengan metode DPPH (Rohman dan Riyanto (2005) dengan modifikasi), kadar fenolik total dengan metode folin cioceltau (Farmakope Herbal Indonesia (2011) dengan modifikasi), perubahan berat badan mencit dan kadar gula darah mencit selama perlakuan (Mayaswari, 2017).

\section{Rancangan Penelitian dan Analisis Data} Rancangan penelitian yang digunakan adalah rancagan acak lengkap (RAL) dengan faktor tunggal berupa pebedaan rasio bubuk kopi robusta dan bubuk daun kersen yang terdiri dari 6 aras perlakuan sebagai berikut:

P1 = Bubuk kopi robusta 100\% : bubuk daun kersen (kontrol) 0\%

P2 = Bubuk kopi robusta 85\% : bubuk daun kersen $15 \%$

P3 = Bubuk kopi robusta 70\% : bubuk daun kersen $30 \%$ 
P4 = Bubuk kopi robusta 55\% : bubuk daun kersen $45 \%$

P5 = Bubuk kopi robusta 40\% : bubuk daun kersen $60 \%$

P6 = Bubuk kopi robusta 25\% : bubuk daun kersen $75 \%$

Masing-masing perlakuan diberikan ulangan sebanyak 3 kali untuk menghindari bias, sehingga diperoleh 18 unit percobaan, setiap unit percobaan dilakukan uji aktivitas antioksidan dan kadar fenolik total. Kelompok perlakuan dengan persentase aktivitas antioksidan dan kadar fenolik tertinggi kemudian digunakan untuk uji in vivo pada mencit yang dikondisikan diabetes.

Uji in vivo pada mencit menggunakan rancangan penelitian The Randomized Post Test Only Control Group Design. Penelitian ini dilakukan pada 3 kelompok perlakuan yang terdiri dari 3 mencit untuk setiap kelompok perlakuan. Kelompok-kelompok perlakuan tersebut, yakni:

$\mathrm{K} 1$ = pakan standar + aloksan + aquades (kontrol negatif)

$\mathrm{K} 2$ = pakan sandar + aloksan + aquades + glibenklamid (kontrol positif)

$\mathrm{K} 3=$ pakan sandar + aloksan + aquades + produk kopi fungsional dengan persentase aktivitas antioksidan tertinggi.

Analisis data dilakukan menggunakan uji Analysis of Variance (ANOVA) pada taraf nyata $5 \%$ dengan menggunakan software SPSS 21. Jika terjadi perbedaan yang nyata pada hasil pengamatan akan dilakukan uji lanjut dengan uji Least Significant Difference (LSD) pada taraf nyata $5 \%$. Sebelumnya data primer hasil pengamatan pada hewan percobaan diuji normalitas dengan uji Shapiro Wilk untuk melihat sebaran distribusi data dan uji Levene's test untuk melihat homogenitas data (Mayaswari, 2017).

\section{HASIL DAN PEMBAHASAN}

\section{Kadar Fenolik Total}

Kadar fenolik total dari produk kopi fungsional dengan rasio bubuk kopi robusta dan bubuk daun kersen yang berbeda-beda ditentukan menggunakan alat spektrofotometri UV-VIS dengan pereaksi folin ciocalteau. Folin ciocalteau bereaksi dengan senyawa fenolik yang terdapat pada ekstrak dan menghasilkan larutan berwarna yang dapat diukur absorbansinya. Senyawa fenolik ini hanya dapat bereaksi pada suasana basa, oleh karena itu larutan uji dikondisikan basa dengan cara penambahan $\mathrm{Na} 2 \mathrm{CO} 3$, sehingga terjadi disosiasi proton pada senyawa fenol menjadi ion fenolat. Reaksi yang terbentuk ditandai dengan terbentuknya warna biru setelah penambahan $\mathrm{Na} 2 \mathrm{CO} 3$ dan absorbansinya dapat diukur pada panjang gelombong 744,8 $\mathrm{nm}$. Gugus hidroksil dari fenolik akan mereduksi asam heteropoli (fosfomolibdatfosfotungstat) yang terdapat pada folin ciocalteau menjadi kompleks molibdattungstat yang berwarna biru (Alawiyah, 2016). Semakin pekat warna biru yang terbentuk, maka kadar fenolik pada kopi fungsional semakin besar yang artinya semakin banyak ion fenolat yang mereduksi asam heteropoli menjadi kompleks molibdattungstat. Hasil pengamatan kadar fenolik total minuman kopi fungsional dapat ditinjau pada Gambar 1.

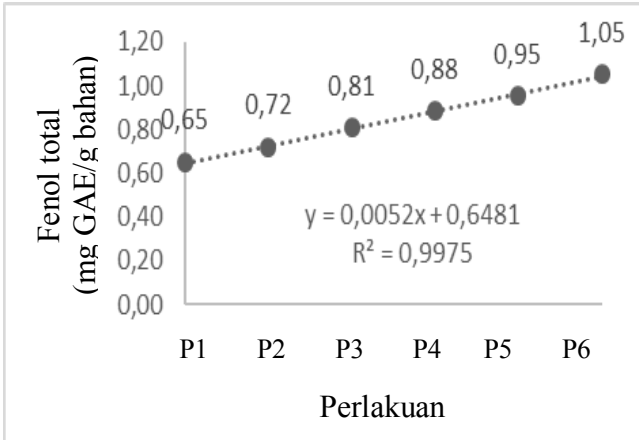

Gambar 1. Grafik pengaruh rasio bubuk daun kersen dan bubuk kopi robusta terhadap kadar fenolik total minuman kopi fungsional

Keterangan:

P1 =Bubuk kopi robusta 100\%: bubuk daun kersen (kontrol) $0 \%$

P2 = Bubuk kopi robusta 85\%: bubuk daun kersen 15\% P3 = Bubuk kopi robusta 70\%: bubuk daun kersen 30\% P4 = Bubuk kopi robusta 55\%: bubuk daun kersen $45 \%$ P5 = Bubuk kopi robusta 40\%: bubuk daun kersen $60 \%$ P6 = Bubuk kopi robusta 25\%: bubuk daun kersen 75\% Berdasarkan Gambar 1, dapat diamati bahwa terjadi hubungan yang berbanding 
lurus antara peningkatan rasio bubuk daun kersen terhadap peningkatan kadar fenolik total pada minuman kopi fungsional, dimana perlakuan terbaik ditemukan pada rasio bubuk daun kersen $75 \%$ dan bubuk kopi robusta $25 \%$ dengan kadar fenolik total sebesar $1,05 \mathrm{mg}$ GAE/g bahan atau setara dengan $0,10 \%$, sedangkan kadar fenolik total terendah pada perlakuan $0 \%$ bubuk daun kersen dan $100 \%$ bubuk kopi robusta dengan kadar fenolik total sebesar $0,65 \mathrm{mg}$ $\mathrm{GAE} / \mathrm{g}$ bahan atau setara dengan 0,065\%. Hal ini disebabkan karena berdasarkan analisis bahan baku, kadar fenolik total pada bubuk daun kersen adalah sebesar $1,14 \mathrm{mg}$ $\mathrm{GAE} / \mathrm{g}$ bahan, lebih besar dibandingkan dengan kadar fenolik total bubuk kopi robusta yang hanya $0,65 \mathrm{mg} \mathrm{GAE} / \mathrm{g}$ bahan. Sehingga penambahan bubuk daun kersen pada bubuk kopi robusta mampu meningkatkan kandungan total fenol dari minuman kopi dan besaran peningkatan kandungan total fenol dari minuman kopi sejalan dengan besaran bubuk daun kersen yang ditambahkan.

\section{Aktivitas Antioksidan}

Antioksidan adalah senyawa yang dapat menghambat, mencegah atau menghilangkan kerusakan oksidatif pada suatu molekul (Halliwel dan Gutteridge, 1999). Hasil pengamatan pengaruh rasio bubuk kopi robusta dan bubuk daun kersen terhadap aktivitas antioksidan minuman kopi fungsional dapat ditinjau pada Gambar 2.

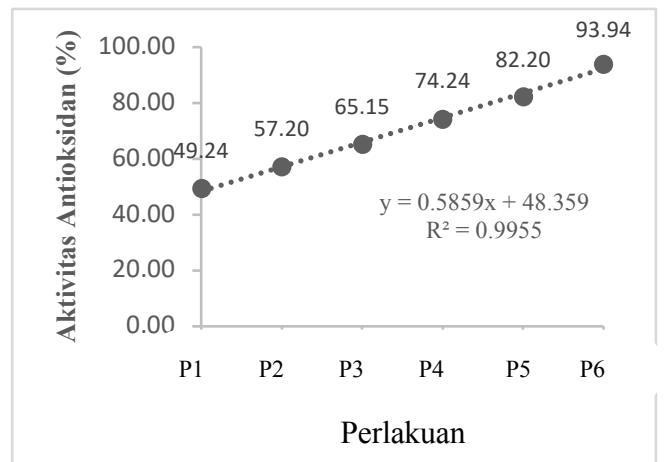

Gambar 2. Grafik Pengaruh Rasio Bubuk Kopi Robusta dan Bubuk Daun Kersen Terhadap Aktivitas Antioksidan Minuman Kopi Fungsional Antidiabetes

Keterangan:
P1 = Bubuk kopi robusta 100\% : bubuk daun kersen (kontrol) 0\%

P2 = Bubuk kopi robusta 85\% : bubuk daun kersen 15\% P3 = Bubuk kopi robusta 70\% : bubuk daun kersen $30 \%$ P4 = Bubuk kopi robusta 55\% : bubuk daun kersen $45 \%$ P5 = Bubuk kopi robusta 40\% : bubuk daun kersen $60 \%$ P6 = Bubuk kopi robusta 25\% : bubuk daun kersen $75 \%$

Hasil pengamatan menunjukan bahwa aktivitas antioksidan tertinggi diperoleh dari rasio bubuk daun kersen sebesar $75 \%$ dan bubuk kopi robusta sebesar $25 \%$ dengan rata-rata aktivitas antioksidan sebesar 88,26\%. Sedangkan aktivitas antioksidan terendah pada rasio bubuk daun kersen $0 \%$ dan bubuk kopi robusta $100 \%$ dengan rata-rata sebesar 49,24\%. Berdasarkan pada Gambar 2 juga dapat diamati bahwa terjadi tren peningkatan aktivitas antioksidan minuman kopi fungsional sejalan dengan peningkatan rasio bubuk daun kersen pada minuman kopi fungsional. Hal ini disebabkan karena aktivitas antioksidan pada bubuk daun kersen berdasarkan analisis bahan baku adalah lebih besar dibandingkan bubuk kopi robusta, yakni $89,77 \%$ berbanding $50 \%$. Sehingga peningkatan rasio bubuk daun kersen akan lebih mampu meningkatkan aktivitas antioksidan minuman kopi fungsional.

Peningkatan aktivitas antioksidan ini juga sejalan dengan peningkatan kadar fenolik total pada prouk. Berdasarkan penelitian Holsova dkk (2002), terdapat hubungan yang signifikan antara kadar fenolik total dan kadar rutin (kuersetin-3rutinosida) terhadap aktivitas antioksidan pada sampel buckwheat. Menurut Marjoni dkk (2015), Dari sejumlah penelitian pada tanaman obat dilaporkan bahwa terdapat banyak tanaman obat yang mengandung antioksidan dalam jumlah besar. Efek antioksidan terutama disebabkan karena adanya senyawa fenol seperti flavonoida dan asam fenolat.

Mekanisme senyawa fenolik sebagai antioksidan didasarkan pada kemampuan gugus fenol untuk mengikat radikal bebas dengan memberikan atom hidrogen melalui proses transfer elektron, sehingga fenol berubah menjadi radikal fenoksil. Radikal 
fenoksil yang terbentuk sebagai hasil reaksi fenol dengan radikal bebas kemudian akan menstabilkan diri melalui efek resonansi. Karena alasan ini maka derivat dari fenol merupakan donor hidrogen yang baik yang dapat menghambat reaksi yang terjadi oleh senyawa radikal (Jasson, 2005).

\section{Penurunan Kadar Gula Darah Mencit}

Rata-rata kadar gula darah mencit setelah 2 hari injeksi aloksan yang dinyatakan sebagai kadar gula darah hari ke0 dan kadar gula darah mencit setelah 7 hari pemberian perlakuan dan dipuasakan 24 jam dinyatakan sebagai kadar gula darah hari ke8 dapat ditinjau pada Gambar 3.

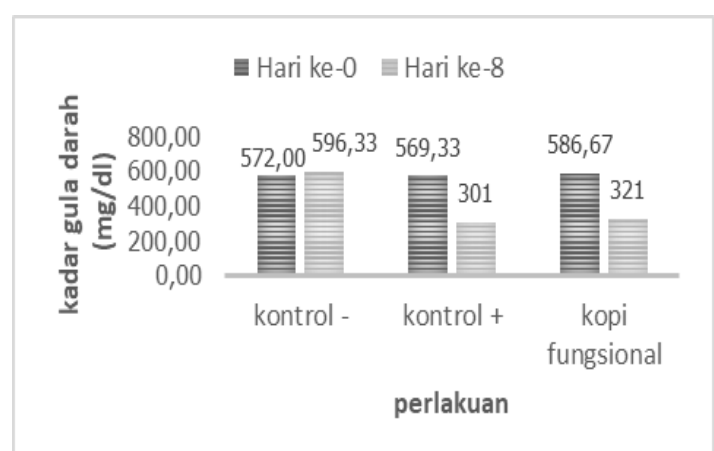

Gambar 3. Diagram Batang Penurunan Kadar Gula Darah Mencit Hari Ke-0 Hingga Hari Ke-8

Berdasarkan Gambar 3 dapat diamati bahwa rata-rata kadar gula darah puasa pada mencit hari ke-0 adalah diatas 200 $\mathrm{mg} / \mathrm{dl}$, sehingga dikategorikan diabetes dan memenuhi kriteria inklusi sebagai hewan uji diabetes. Rata-rata kadar gula darah yang berbeda-beda pada hari ke-0 meski diberikan aloksan dengan dosis yang sama, dapat diakibatkan karena daya tahan tubuh mencit tidak sama sehingga kondisi awal diabetes tidak seragam (Jung $d k k$., 2006).

Pada kelompok perlakuan kontrol negatif memiliki rata-rata kadar gula darah puasa setelah injeksi aloksan sebesar 572 $\mathrm{mg} / \mathrm{dl}$ dan setelah 7 hari hanya diberikan aquades dan pakan standar, kadar gula darah meningkat menjadi $596 \mathrm{mg} / \mathrm{dl}$. Kelompok perlakuan kontrol positif pada hari ke-0 memiliki kadar gula darah sebesar 569 $\mathrm{mg} / \mathrm{dl}$ dan mengalami penurunan menjadi
$301 \mathrm{mg} / \mathrm{dl}$ setelah 7 hari perlakuan menggunakan obat glibenklamid, pakan standar dan aquades ad libitum. Pada kelompok perlakuan dengan pemberian produk minuman kopi fungsional, diperoleh rata-rata kadar gula darah puasa sebesar $587 \mathrm{mg} / \mathrm{dl}$ dan mengalami penurunan menjadi $321 \mathrm{mg} / \mathrm{dl}$ setelah 7 hari perlakuan. Sehingga dapat dikatakan bahwa produk minuman kopi fungsional dengan volume pemberian $0,5 \mathrm{ml}$ per hari dari satu cangkir kopi fungsional konsentrasi $9 \mathrm{gram} / 200 \mathrm{ml}$ terbukti dapat memberikan efek hipoglikemik pada mencit yang dikondisikan diabetes, namun kondisi normal dari mencit yang dikondisikan diabetes belum tercapai.

Hal ini dapat diakibatkan oleh durasi penelitian yang tergolong singkat, sehingga peran dari produk dalam mengatasi radikal bebas dan stres oksidatif akibat kondisi diabetes masih belum teramati secara optimal. Sedangkan untuk besaran penurunan dan presentase penurunan kadar gula darah puasa untuk setiap kelompok perlakuan selama 7 hari, dapat dilihat pada Tabel 1.

Tabel 1. Presentase Penurunan Kadar Gula Darah Puasa

\begin{tabular}{ccc}
\hline $\begin{array}{c}\text { Kelompok } \\
\text { perlakuan }\end{array}$ & $\boldsymbol{\Delta}(\mathbf{m g} / \mathbf{d l})$ & $\begin{array}{c}\% \\
\text { Penurunan }\end{array}$ \\
\hline $\begin{array}{c}\text { Kontrol } \\
\text { negatif }\end{array}$ & -24 & $-4,20$ \\
$\begin{array}{c}\text { Kontrol positif } \\
\begin{array}{c}\text { Produk kopi } \\
\text { fungsional }\end{array}\end{array}$ & 268 & 47,10 \\
\hline Keterangan: (-): berarti peningkatan &
\end{tabular}

Pada kelompok kontrol negatif mengalami peningkatan sebesar $24 \mathrm{mg} / \mathrm{dl}$ dari hari ke-0 hingga hari ke-8. Hal ini terjadi karen sel $\beta$ pulau langerhans dalam pangkreas mengalami kerusakan akibat diinduksi aloksan, sehingga pankreas tidak mampu menghasilkan insulin dan memperburuk kondisi diabetes. Kondisi ini berbeda dengan kelompok perlakuan kontrol positif dan kelompok perlakuan produk, dimana ditemukan rata-rata penurunan kadar gula darah puasa sebesar $268 \mathrm{mg} / \mathrm{dl}$ dan 266 mg/dl. Pada kelompok kontrol 
positif, penurunan kadar gula darah puasa dapat terjai karena pada kelompok tersebut diberikan perlakuan dengan obat glibenklamid, yaitu obat komersial yang sering digunakan dalam terapi medis.

Menurut Tjay dan Raharja (2002), Glibenklamid memiliki efek hipoglikemik kerena mampu menstimulasi pengeluaran insulin pada setiap pemasukan glukosa. Selain itu, berdasarkan penelitian Jeli dan Mukiyah (2011), pemberian glibenklamid dapat membantu proses perbaikan kerusakan pankreas akibat induksi aloksan yang ditinjau dari penurunan diameter pulau lingerhans dan jumlah sel $\beta$ di dalamnya. Sedangkan pada kelmpok perlakuan produk kopi fungsional, penurunan kadar gula darah puasa dapat terjadi karena potensi dari aktivitas antioksidan pada produk kopi fungsional yang relatif besar, yakni $89,77 \%$. Pada penelitian terdahulu dari Hairani (2018), aktivitas antioksidan sebesar $31,44 \%$ pada produk sosis analog telah mampu menurunkan kadar gula darah sebesar 387 $\mathrm{mg} / \mathrm{dl}$ dalam rentang penelitian 14 hari.

Kemampuan

antioksidan

menurunkan kadar gula darah didasarkan dari kemampuan antioksidan dalam memperbaiki fungsi dari $\beta$-sel, meningkatkan sensitivitas insulin, dan menjaga sel endotel vaskular. Selain itu, antioksidan dapat mengurangi stres oksidatif dan beberapa agen hipoglikemik yang mampu mengurangi stres oksidatif secara tidak langsung mengurangi kadar gula darah dan mencegah hiperinsulinemia serta secara langsung bekerja sebagai agen penangkal radikal bebas (Ruhe dan McDonald, 2001). Selain aktivitas antioksidan yang tinggi pada produk, kandungan asam klorogenat pada biji kopi robusta juga diduga berperan dalam menurunkan kadar gula darah mencit. Asam klorogenat diduga mampu menghambat aktivitas enzim alfa glukooksidase (Paynter dkk., 2006), apabila aktivitas dari enzim alfa glukooksidase terhambat maka penyerapan glukosa dari saluran pencernaan juga terhambat sehingga kadar gula di darah berkurang (Utami dan Desty, 2013).
Berdasarkan hasil uji lanjut menggunakan LSD dan berdasarkan pula pada tabel 1, dapat disimpulkan bahwa terjadi penurunan yang signifikan antara kadar gula darah puasa pada kontrol negatif terhadap kontrol positif dan produk kopi fungsional, namun tidak berbeda signifikan antara kontrol positif terhadap produk kopi fungsional. Perlakuan terbaik diperoleh dari kelompok mencit yang diberikan perlakuan obat glibenklamid, namun perbedaan ini hanya sedikit sekali dan tidak signifikan terhadap kelompok mencit yang diberikan terapi kopi fungsional dengan selisih penurunan hanya $2 \mathrm{mg} / \mathrm{dl}$. Sedangkan jika dilihat dari keaktifan motorik, kelompok mencit yang diberikan produk kopi fungsional lebih aktif dibandingkan kelompok mencit lainnya. Hal ini dapat disebabkan karena pada produk kopi fungsional masih mengandung kafein yang dapat bekerja sebagai perangsang psikoaktif dan diuretik ringan (Maughan, 2003).

\section{Penurunan Berat Badan Mencit}

Berat badan mencit menjadi salah satu indikator yang penting untuk diamati. Pengukuran berat badan mencit dilakukan pada awal sebelum injeksi aloksan yang dinyatakan sebagai berat badan awal, dua hari setelah injeksi aloksan yang dinyatakan sebagai berat badan hari ke-0 dan setelah 7 hari pemberian perlakuan dan dipuasakan 24 jam sebagai berat badan hari ke-8 yang dapat dilihat pada Gambar 4.

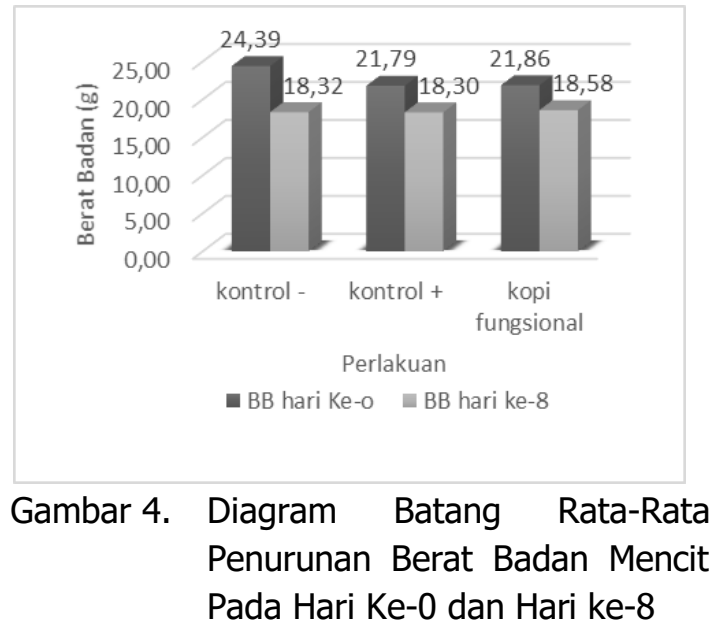


Berdasasrkan Gambar 4, dapat diamati bahwa rata-rata berat badan mencit mengalami penurunan selama dikondisikan diabetes. Rata-rata penurunan berat badan mencit pada kelompok perlakuan negatif adalah sebesar $6,07 \mathrm{~g}$, pada kelompok perlakuan positif sebesar $3,49 \mathrm{~g}$ dan pada kelompok perlakuan kopi fungsional sebesar 3,28 g. Selisih penurunan berat badan mencit pada kelmopok kontrol positif dan kelompok kopi fungsional hampir setengah dari penurunan berat badan mencit pada kelompok kontrol negatif.

Hal ini berarti bahwa, kelompok mencit diabetes yang diberikan terapi obat glibenklamid dan terapi kopi fungsional, efektif dalam meminimalisir sekresi urin yang menyebabkan penurunan berat badan pada mencit diabetes yang ditinjau dari 7 hari terapi. Sedangkan, pada penelitian Pratiwi (2019), berat badan tikus diabetes rata-rata mengalami penurunan sebesar $6 \mathrm{~g}$ pada kelompok tikus yang diberikan terapi ekstrak eugenol dengan dosis $15 \mathrm{mg} / \mathrm{kg}$ BB selama 10 hari.

Menurut Rizmahardian (2008), Terjadinya penurunan bobot badan pada kondisi diabetes diakibatan karena ketidaksediaaan glukosa dalam sel karena insulin yang membatasi proses glukoneogenesis sangat sedikit atau tidak ada sama sekali. Glukosa yang dihasilkan kemudian akan terbuang melalui urine akibatnya, terjadi pengurangan jumlah jaringan otot dan jaringan adipose secara signifikan dan terjadi penurunan bobot berat badan.

\section{KESIMPULAN}

Berdasarkan hasil analisis dan uraian pembahasan yang terbatas pada ruang lingkup penelitian, maka ditarik beberapa kesimpulan sebagai berikut:

1. Peningkatan rasio bubuk daun kersen pada minuman kopi fungsional memberikan pengaruh yang signifikan terhadap peningkatan kadar fenolik total dan aktivitas antioksidan dari minuman kopi fungsional.
2. Terapi menggunakan produk minuman kopi fungsional dengan rasio bubuk kopi robusta $25 \%$ dan bubuk daun kersen $75 \%$ pada mencit diabetes memberikan pengaruh penurunan kadar gula darah puasa yang signifikan dan mendekati atau hampir sama dengan perlakuan pada mencit yang diberikan obat glibenklamid (obat hipoglikemik komersial) dengan rata-rata penurunan kadar gula darah puasa sebesar 266 $\mathrm{mg} / \mathrm{dl}$ pada kelompok mencit yang diberikan produk kopi fungsional dan $268 \mathrm{mg} / \mathrm{dl}$ pada kelompok mencit yang diberikan obat glibenklamid.

3. Seluruh kelompok mencit diabetes mengalami penurunan berat badan selama perlakuan, penurunan berat badan pada kontrol negatif dua kali lipat dari penurunan berat badan kontrol positif dan produk kopi fungsional.

\section{DAFTAR PUSTAKA}

Alawiyah, A. L. 2016. Kadar Fenol Total dan Bioaktivitas Flavon dari Kulit Kacang Tanah sebagai Antioksidan dan Antiproliferasi Terhadap Sel Kanker Hela. Tesis. Institut Pertanian Bogor. Bogor.

Badan Penelitian dan Pengembangan Kesehatan Kementerian Kesehatan RI. Riset Kesehatan Dasar 2013. Jakarta: Depkes RI.

Castelnuovo, A. D., Romina D. G., Licia L. dan Giovanni D. G. 2012. Consumtion of Cocoa, Tea and Coffee and Risk of Cardiovascular Disease. European Journal of Internal Medicine. (23): 15-25.

Chandra, D., R. H. Ismono dan Eka K. 2012. Prospek Perdagangan Kopi Robusta Indonesia di Pasar Internasional. Lampung: Fakultas Pertanian Universitas Lampung.

Clarke, R. J. dan R. Macrae. 1987. Coffe Chemistry (volume 1). London: Elsevier Applied Science.

Direktorat Jendral Bina Kefarmasian dan Alat Kesehatan. 2011. Suplemen II 
Versi Online:

http://www.profood.unram.ac.id/index.php/profood e-ISSN: 2443-3446

Farmakope Herbal Indonesia Edisi I. Jakarta: Kementrian Kesehatan RI.

Guariguata, L., D.R. Whiting, I. Hambelton, J. Beagley, U. Linnenkamp dan J.E. Shaw. 2014. Global Etimates of Diabetes Prevalance for 2013 and Projections for 2035. Elsevier. 103: 137-149.

Hairani, M., Satrijo S., Dody H. 2017. Uji Aktivitas Antioksidan Sosis Analog Tempe Dengan Penambahan Tepung Ubi Jalar Ungu Terhadap Penurunan Kadar Gula Darah Mencit Diabetes. Pro Food (Jurnal IImu dan Teknologi Pangan). 4: 383-390.

Halliwel, B., dan J.M.C. Gutteridge. 1999. Free Radicals in Biology and Medicine. New York: Oxford University Press.

Harfina, F., Saiful B. dan Awaluddin S. 2012. Pengaruh Serbuk Daun Puguntano (Curanga fel-terrae merr.) pada Pasien Diabetes Mellitus. Journal of Pharmaceutics and Pharmacology, 1(2): 112-118.

Holsova, M. V. Fiedlerova, H. Smrcinova, M. Orsak, J. Lachman dan S. Vavreinova. 2002. Buckwheat-the Source of Antioxidant Activity in Functional Foods. Food research international. 35: 207-211.

Jasson, N. 2005. The Determination of Total Phenolic Compounds in GreenTea.http://folinciocalteu/metho d/colorimetric. Diakses pada 4 Agustus 2019.

Jeli, M.M. dan SN. N. Mukiyah. 2011. Pengaruh Pemberian Infusa Tumbuhan Sarang Semut (Hydnophytum formicarum) Terhadap Gambaran Histologi Pankreas pada Tikus (Rattus norvegicus) Diabetes Terinduksi Aloksan. PharmaMedika. 1 (3): 2002014.

Jung, Mankil, Moonsoo P., Hyun C.L., YoonHo K., Eun Seok K. dan S.K. Kim. 2006. Antidiabetic Agents from Medicinal Plants. Current Medicinal Chemistry. (13): 1203-1218.

Kuntorini, Evi Mintowati, Setya F., dan Maria D. A. 2013. Struktur Anatomi dan Uji
Pro Food (Jurnal IImu dan Teknologi Pangan)

Vol 6 No. 1 Mei 2020

ISSN: 2443-1095

Aktivitas Antioksidan Ekstrak Metanol Daun Kersen (Muntingia calabura). Prosiding Semirata FMIPA Universitas Lampung. Lampung. Hal. 291-295.

Marjoni, M. R., Afrinaldi, A. D. Devita. 2015. Kandungan Total Fenol dan Aktivitas Antioksidan Ekstrak Air Daun Kersen (Muntingia calabura L.). Jurnal Kedokteran YARSI 23 (3): 187-196.

Maughan, J. 2003. Caffeine Ingestion and Fluid Balance: a review. Journal of Human Nutrition Dietetics. 16: 411420.

Mayaswari, L. N. 2017. Perbandingan Efikasi Ekstrak Ramuan Obat Tradisional Khas NTB Dengan Glibenklamid Dalam Menurunkan Gula Darah Mencit BALB/C yang Diinduksi Aloksan. Skripsi. Fakultas Kedokteran. Universitas Mataram. Mataram.

Paynter N.P. 2006. More Support for Coffee Antiadiabetes Benefits, Nutraingredient. American Journal of Epidemiology: 1075-1084.

Pratiwi, Iin P. 2019. Evaluasi Pemberian Senyawa Eugenol Isolat Bunga Cengkeh (Syzygium Aromaticum) Terhadap Kadar Gula Darah Mencit Diabetes. Skripsi. Fakultas Kedokteran. Universitas Mataram. Mataram.

Purwaningsih, H., Sri A. dan Umar S. 2002. Pengaruh Penyangraian Biji Kopi dengan Microwave Oven Terhadap Profil Aroma dan Organoleptik Seduhan Kopi Arabika. Agrosains. 15 (1) : 73-83.

Puspitasari, Anita Dewi dan Lean Syam Prayogo. 2017. Perbandingan Metode Ekstraksi Maserasi dan Sokletasi Terhadap Kadar Fenolik Total Ekstrak Etanol Daun Kersen (Muntingia calabura). Jurnal IImiah Cendekia Eksakta: 1-7.

Rizmahardian, A. K. 2008. Kaitan antara Metabolisme Karbohidrat dan Diabetes Mellitus. Pontianak: Universitas Pontianak.

Rohman, A. dan S. Riyanto. 2005. Daya Antioksidan Ekstrak Etanol Daun Kemuning (Murraya paniculata (L) 
Jack) Secara In Vitro. Majalah Farmasi Indonesia. 16 (3) : 136-140.

Ruhe, R. C., dan R. B. McDonald. 2001. Use of Antioxidant Nutrients in the Prevention and Treatment of Type 2 Diabetes. Journal of the American College of Nutrition, 20 (5): 363S369S.

Sani, R.N., Fithri C.N., Ria D.A., dan Jaya M.M. 2014. Analisis Rendemen Dan Skrining Fitokimia Ekstrak Etanol Mikroalga Laut Tetraselmis chuii. Jurnal Pangan dan Agroindustri. (2): 121-126.

Sari, L. O. R. K. 2006. Pemanfaatan Obat Tradisional dengan Mempertimbangkan Manfaat dan Keamanannya. Majalah IImu Kefarmasian. 3(1): 1-7.

Siddiqua, Ayesha, K.B. Premakumari, S. Roukiya, Vithya dan Savitha. 2010. Antioxidant Activitiy and Estimation of Total Phenolic Content of Muntingia Calabura by Colorimetry. International Journal of ChemTech Research. 2(1): 205-208.

Stevani, H., Nurul H. B., Husnul A. T. 2017. Efektifitas Rebusan Daun Kersen (Muntingia calabura L) Terhadap Penurunan Kadar Glukosa Darah Pada Mencit (Mus musculus). Jurnal Kesehatan. 1-5.

Tjay, T. H. dan K. Raharja. 2002. Obat-obat Penting. Jakarta: Elex Media Komputind.

Utama, R. P. 2011. Uji Aktivitas Anti Diabetes Fraksi Etil Asetat Daun Kersen (Muntingia calabura L.) pada Mencit Diabetes Akibat Induksi Aloksan. Skripsi. Fakultas Farmasi. Universitas Jember. Jember.

Utami, Prapti dan Desty Ervira P. 2013. The Miracle of Herbs. Jakarta: PT. AgroMedia Pustaka. 